\title{
Prevalence of Escherichia coli O157:H7 in Drink from Different Food Premises in Kota Samarahan Sarawak
}

\author{
NILLIAN ELEXSON*, AMIZA NUR, DIYANA NUR, ZAKIRAH AMIRAH \& BEBEY GRACE \\ Faculty of Resource Science and Technology, Universiti Malaysia Sarawak, 94300, Kota Samarahan, Sarawak, \\ Malaysia. \\ *Corresponding author: nelexson@unimas.my
}

\begin{abstract}
Contamination of drinks with Escherichia. coli O157:H7 served in food premises such as restaurants can cause haemorrhagic colitis and haemolytic uremic syndrome to humans. The presence or absence of faecal pathogen was demonstrated using the coliform group as indicator microorganisms. Therefore, this study was conducted to detect the presence of E. coli O157:H7 in drinking water from food restaurant premises in Kota Samarahan and Kuching to ensure safe and potable drinking water is served to the consumer. A total of thirty $(n=30)$ drink samples including six types of each of the samples are cold plain water, iced tea, iced milo, syrup and iced milk tea. Most Probable Number (MPN) procedure was used in this study to enumerate the MPN values of coliform bacteria in each drink collected. A total of $53.33 \%$ (16/30) of the drink samples showed positive E. coli detection. Then, the PCR assay showed $6.25 \%$ (one out of 16 isolates) samples were positive and carried stx 1 gene produced by E. coli O157:H7 in iced milo sample types. This study showed the drinks collected from food premises were contaminated with faecal contamination, which was not safe to drink by the consumer. Therefore, preventive actions should be taken to prevent foodborne illness outbreak in the future.
\end{abstract}

Keywords: E. coli, E. coli O157:H7, food premises, MPN method, PCR assay

Copyright: This is an open access article distributed under the terms of the CC-BY-NC-SA (Creative Commons Attribution Non CommercialShare Alike 4.0 International License) which permits unrestricted use, distribution and reproduction in any medium, for non-commercial purpose, provide the original work of the author(s) is properly cited.

\section{INTRODUCTION}

Consumption of contaminated drinking water might be linked to severe life-threatening disease also known as waterborne diseases. Foodborne and waterborne diseases always become a major problem in developing countries compared to developed countries (Portier et al., 2013). According to the World Health Organization (WHO, 2002), contaminated drinking water may become a major burden to human health as it can contribute to waterborne disease. There are several types of waterborne outbreak agents that can survive in water including drinking water which can harm human health such as bacterial agents, viral agents, pathogenic agents and chemical agents (Leclerc, Schwartzbrod \& Dei-Cas, 2002). This pathogenic agent can also be transmitted directly from dermal contact with water. Bacterial pathogens that are well known in causing waterborne diseases such as diarrheal illness, typhoid fever, cholera, cryptosporidium, giardiasis and legionellosis include Escherichia coli, Salmonella typhi, Vibrio cholera, Cryptosporodium parvum, Giardia lamblia and Legionella pneumophila. It has been reported that between 2011 and 2016, there are 381 cases associated with the protozoan disease worldwide (Efstratiou, Ongerth \& Karanis, 2017). 7\% from 6939 deaths in the United States were associated with several types of pathogens including E. coli transmitted by the faecal-oral route (Gargano et al., 2017). E. coli is a member of the faecal coliform group and commonly used as an indicator to monitor the microbiological quality in drinking. Their presence in drinking water indicates recent faecal contamination which means the potential presence of enteric pathogens (Figueras \& Borrego, 2010). Hygiene standards of food premises may reflect the quality of food and drinks served to the customers. Restaurants and stalls with low sanitary conditions may contribute to the foodborne and waterborne outbreak and may affect many people. Golan et al. (2004) reported that 700 people had contracted a foodborne illness and four children died after eating contaminated meat from a restaurant, while five diners experienced diarrhoea and vomiting after eating raw oysters (Baker et al., 2010). As water is also used in food preparation and making drinks for the customer, it is crucial to abide by the guidelines of drinking water quality standards established by the Ministry of Health Malaysia. The maximum acceptable value for total coliform and E. coli is zero in $100 \mathrm{ml}$ (WHO, 1997). This study is essential in terms of gauging the level of bacteria present in drinking water with $E$. coli as well as determining the quality and safety of the drinking water served from restaurants in Kota Samarahan. The risks of water-related diseases and health problems in local residents might increase by the presence of some pathogenic bacteria in drinking water. Therefore, the objective of this research is to investigate the presence of stx 1 gene of isolated E. coli O157:H7 from drinks in food premises in Kota Samarahan, Sarawak. 


\section{MATERIALS \& METHODS \\ Samples Collection}

A total of 30 drinks with five flavours (iced tea, iced milk tea, syrup, iced milo and plain cold water) of each restaurant were purchased from six food premises in Kota Samarahan. Then, the samples were labelled respectively and stored at $4^{0} \mathrm{C}$ for 2-4 hours and transported to the Microbiology Laboratory 2, Universiti Malaysia Sarawak.

\section{Detection of Faecal Coliform Bacteria}

The most probable number (MPN) procedure is used to estimate microbial densities in many matrices including foods and water. Most Probable Number (MPN) was used referring to the protocol provided by Feng et al. (2013). For the presumptive test, Lauryl Tryptose Broth (LTB) fermentation tubes were used to screen the presence of coliform organisms by observing the gas production within Durham tube. Nine test tube containing sterile LTB broth incorporated with Durham tube in each tube, 3 tubes double strength LTB with $10 \mathrm{~mL}$ portions of drinking water samples, 3 tubes single strength LTB with $1 \mathrm{~mL}$ portions of drinking water samples and 3 tubes single strength of LTB with $0.1 \mathrm{~mL}$ portions of drinking water were inoculated and incubated at $37{ }^{0} \mathrm{C}$. Growth and gas production were observed after 48 hours. A loopful from each of the positive tubes of LTB was streaked onto Eosin Methylene Blue (EMB) agar and incubated for 24 hours at $37^{\circ} \mathrm{C}$. Coliforms bacteria produced small colonies with dark centre while $E$. coli produced shiny metallic green colonies on the EMB agar as shown in Figure 2 . The shiny metallic green colonies were isolated and stroke on the nutrient agar and incubated for 24 hours at $37^{\circ} \mathrm{C}$.

\section{Gram Staining}

Gram staining was carried out based on the protocol provided by Barile (2012). A single colony of bacteria from each agar plate was transferred onto a microscope slide. A drop of distilled water was added to the slide and dried up. Crystal violet was added on the slide, left for one minute and washed with distilled water. The specimen was covered with iodine solution for one minute and washed again with distilled water. Then, $90 \%$ of ethanol was run on the microscope slide until the blue staining colour no longer came off and rinsed with distilled water immediately then flooded with safranin for 45 seconds. The slide was rinsed with distilled water and dry then observed using a microscope. The result is shown in Figure 3.

\section{Genomic DNA Extraction (Boiling Cell Method)}

Extraction of DNA using the boiled-cell method provided by Chai et al. (2007) with minor modification was used to detect the E. coli $0157: \mathrm{H} 7$ in the water sample. A single colony from nutrient agar was transferred into the Luria Bertani (LB) broth and incubated for 24 hours at $37{ }^{\circ} \mathrm{C}$. For each positive broth, $1.5 \mathrm{~mL}$ was centrifuged at $10000 \mathrm{rpm}$ for five minutes to get the pellet then suspend the pellet by adding $500 \mu \mathrm{L}$ of sterile distilled water and vortex vigorously to dissolve the pellet. Boiled for 10 minutes at $97^{\circ} \mathrm{C}$ and allowed to cool at $-20^{\circ} \mathrm{C}$ for 5 minutes. Centrifuged the tube at $10000 \mathrm{rpm}$ for 10 minutes and the supernatant was used as DNA template for PCR assay.

\section{Polymerase Chain Reaction (PCR)}

In this study, E. coli O157:H7 ATCC 43895 is a positive control and the PCR assay was carried out according to Chai et al. (2007). A total of $25 \mu \mathrm{L}$ reaction mixtures were used to perform PCR amplification as shown in Table 1. The primers and PCR conditions as outlined in Table 2 according to Meng, Zhao, Doyle, Mitchell and Kresovich (1997) were utilized to amplify the stx 1 gene in E. coli O157:H7.

Table 1. Master Mix component for PCR.

\begin{tabular}{lc}
\hline Component & 1x reaction $(\boldsymbol{\mu L})$ \\
\hline 5x Green Go Taq ${ }^{\circledR}$ Flexi Buffer & 5.0 \\
25 mM Magnesium Chloride $\left(\mathrm{MgCl}_{2}\right)$ & 2.5 \\
10 mM Deoxyribonucleotide oligophosphates $(\mathrm{dNTPs})$ & 1.25 \\
Forward Primer & 1.0 \\
Reverse Primer & 1.0 \\
DNA template & 5.0 \\
Sterile distilled water & 8.85 \\
Go Taq ${ }^{\circledR}$ Flexi DNA Polymerase $(5 \mathrm{u} / \mu \mathrm{l})$ & 0.4 \\
\hline Total Volume & 25.0 \\
\hline
\end{tabular}


Table 2. Characteristic of primers to detect stx1 gene E. coli O157:H7

\begin{tabular}{llcc}
\hline Primer & Nucleotide sequence & $\begin{array}{c}\text { Target } \\
\text { gene }\end{array}$ & $\begin{array}{c}\text { Amplicon } \\
\text { size (bp) }\end{array}$ \\
\hline Slt1 (Forward Primer) & TGT AAC TGG AAA GGT GGA GTA TAC & Stx1 gene & 210 \\
Slt1 (Reverse Primer) & GCT ATT CTG AGT CAA AAA ATA AC & & \\
\hline
\end{tabular}

\section{Agarose Gel Electrophoresis (AGE)}

A total of $5 \mu \mathrm{L}$ of PCR products was loaded into the agar and undergo electrophoresis for 47 minutes at $90 \mathrm{~V}$. The PCR products were viewed using UV transilluminator after staining with ethidium bromide (EtBr). The result for PCR products for the detection of stx gene in E. coli $\mathrm{O} 157: \mathrm{H} 7$ with expected size $210 \mathrm{bp}$ from different restaurants on gel electrophoresis was shown in Figure 4.

\section{RESULTS}

In the presumptive test, the three-tube analyses of the MPN method were used to analyse E. coli in drink samples collected from six restaurants in Kota Samarahan. Lauryl Tyrptose broth was used to enrich the faecal coliform in the water samples. The broth turned cloudy and the presence of gas in Durham tubes indicated that there was faecal coliform grown in water samples. MPN value was recorded based on the gas produced in each positive test tube. The averages of the MPN values between the drinks were shown in Figure 1. Drink sample A (iced milo) had the highest mean followed by drink sample E (iced milk tea), drink samples C (iced tea), drink sample B (syrup) and drink sample D (cold plain water).

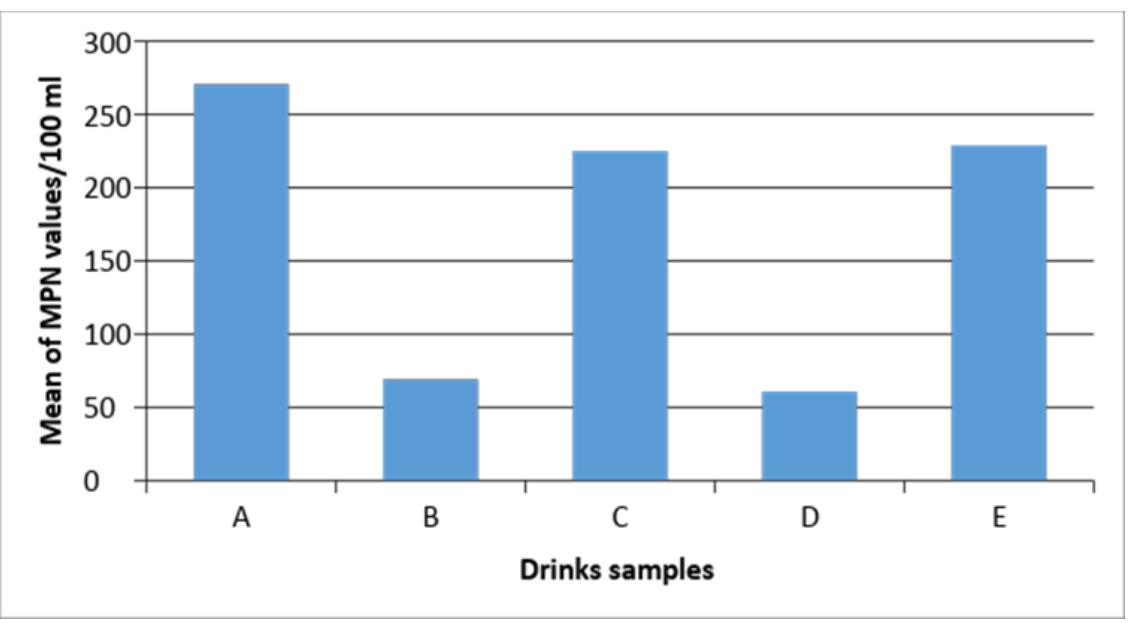

Figure 1. The average of MPN values/100 ml of drink samples recorded six restaurants based on samples types. Sample A = iced milo, Sample E = iced milk tea, Samples C = iced tea, Sample B = syrup and Sample D = cold plain water.

All 16 isolates of $E$. coli that produced green metallic sheen with dark centre colonies on EMB agar, as shown in Figure 2, after subjected for Gram staining. EMB is a selective medium for gram-negative bacteria where the combination of dyes eosin and methylene blue inhibits Gram-positive bacteria to grow on the agar. E. coli is able to ferment lactose rapidly and produced acid end-products. The microscopic examination results on the 16 isolates showed that $100 \%$ of the isolates were Gram-negative, rod-shaped and non-spore forming bacteria.

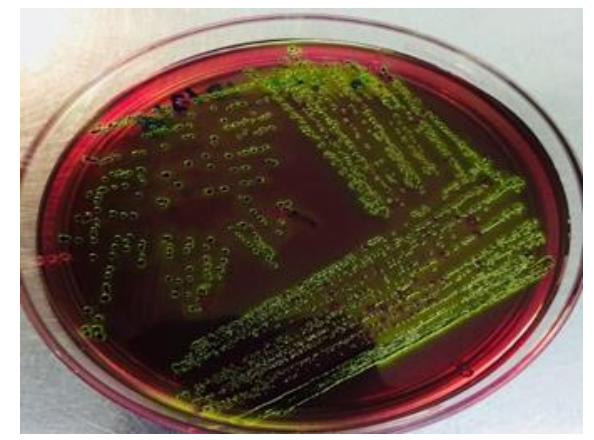

Figure 2. Green metallic sheen colonies produced on EMB agar. 


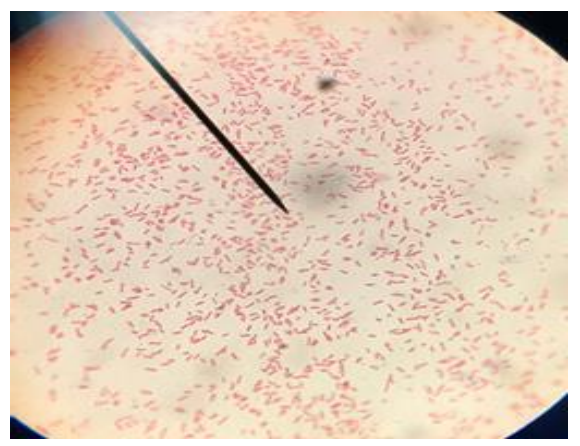

Figure 3. Gram staining result shows Gram-negative, rod-shaped and non-spore forming bacteria under Oil Immersion lens 100x.

A total of 16 isolates from drinks water samples that were identified as E. coli through gram staining and morphology identification were subjected to detect the stx 1 gene using PCR assay. E. coli O157:H7 ATCC 43895 was used as a positive control to validate the PCR assay and to exclude the false-negative result while sterile distilled water was used as a negative control. As a result, as shown in Figure 4, there was only one (6.25\%) out of 16 isolates that were positives to carry stx 1 gene.

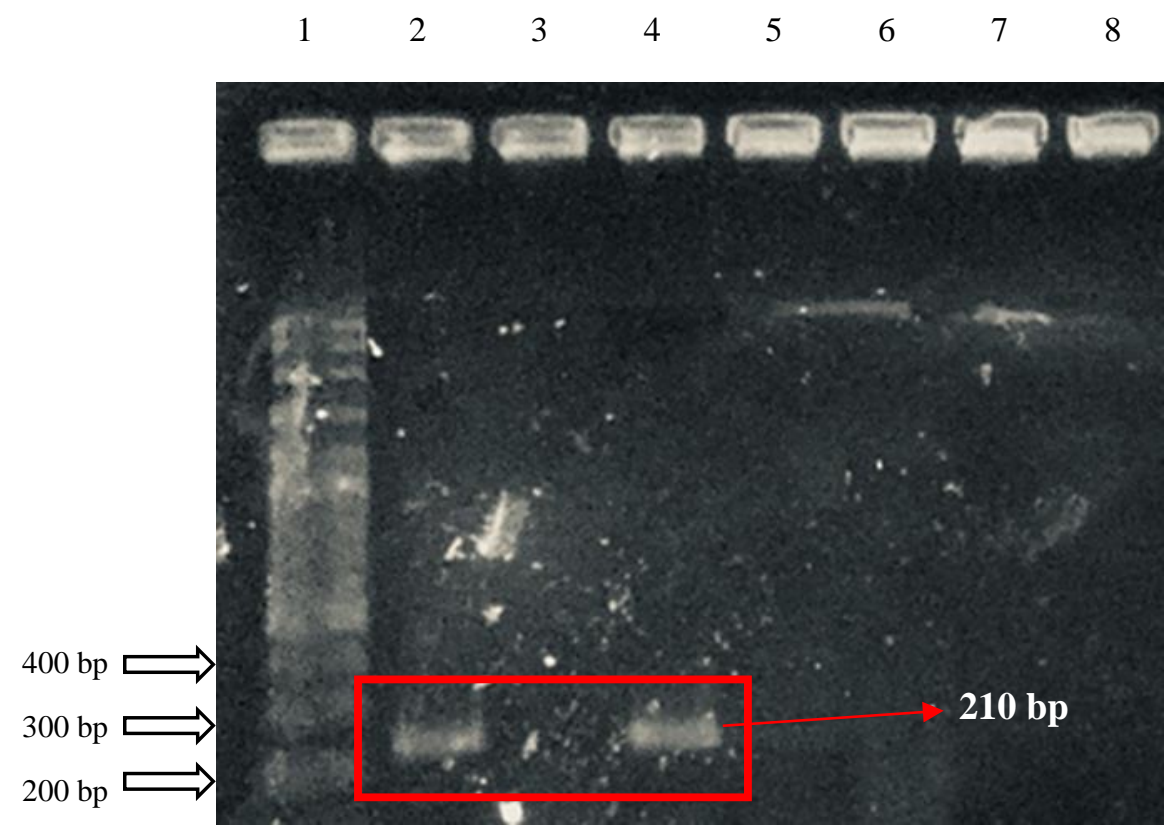

Figure 4. Lane 1: $1 \mathrm{~kb}$ DNA ladder (Vivantis), Lane 2: Positive control, E. coli O157:H7 ATCC 43895, Lane 3: Negative control, Lane 4: Ice milo drink, Lane 5: Cold plain water, Lane 6: Iced tea, Lane 7: Syrup, Lane 8: Iced milk tea.

\section{DISCUSSION}

This study was designed to determine the detection of $E$. coli $\mathrm{O} 157: \mathrm{H} 7$ in drinks sold from six different restaurants in Kota Samarahan. The main aim was to investigate the level of personal and environmental hygiene practices in restaurants. MPN culture method was used for enumeration of total coliform bacteria in samples collected from six restaurants in Kota Samarahan as it is commonly used by microbiologists in analysing water quality, food microbiology and public health. Drink samples from all six restaurants showed positive results in the presumptive test where it initially indicated the presence of coliform bacteria. The quality of drinking water was tested by detecting the presence of coliform bacteria because it is expensive and time-consuming to detect different pathogens as their presence is usually very low in number (Rompré, Servais, Baudart, De-Roubin and Laurent, 2002). Therefore, in this study MPN method is used to detect one of the coliform bacteria, E. coli which is also known as indicator microorganisms for the presence of faecal contamination in the samples. In this study, Lauryl Sulfate Tryptose broth was used as the production of gas could serve not only as a presumptive test but also a confirmation test (Gerba, 2009). Samples from CS9 showed the highest 1100 MPN value in iced tea, syrup and cold plain water which implies that drinks sold in the restaurants are generally unhygienic. The presence of coliform bacteria can be the risk factor for the transmission of disease causative agents such as Salmonella, Shigella 
and other enteropathogenic E. coli (Newell et al., 2010) which are not specifically investigated in this study. The MPN values of coliform bacteria must be absence in drinking water and water that are used to prepare food which is rated excellent and potable whereas MPN value more than 50 indicates that there are pollution and contamination in water and considered as unfit for human consumption (Uyttendaele et al., 2015). In the completed test, all the non-potable samples were recorded based on the production of greenish metallic sheen colonies on selective media, EMB agar. The EMB agar is used to select only gram-negative bacteria to grow and to differentiate between faecal coliforms and non-faecal coliform bacteria. All the positive colonies on EMB agar were observed under the oil immersion lens and $100 \%$ of the samples were confirmed as E. coli. E. coli has an additional outer membrane which is made of phospholipids and lipopolysaccharides. (Tokuda \& Matsumaya, 2004). The cell wall of the bacteria consists of negative charge due to the presence of lipopolysaccharides on the outer membrane and because of that, E. coli does not retain crystal violet during Gram staining.

In the detection of stx 1 gene, the expected size of the PCR product is $210 \mathrm{bp}$ as shown in Figure 4. This indicates the presence of stx 1 gene in the samples collected. This desired gene was amplified as it is suitable for sample evaluation especially during the E. coli $\mathrm{O} 157: \mathrm{H} 7$ outbreak in food or water. From the result, it was found that out of 30 drink samples, $3.33 \%$ were positive for st $x 1$ gene which is isolated from iced milo drinks. It means that the drinks contained pathogenic E. coli O157:H7 strain which is an indicator for faecal contamination. The massive outbreak related to $E$. coli was during 2011 in Europe, which caused by the strain of Shiga toxin-producing $E$. coli O104:H4 and the strain also frequently referred to as EHEC. Other than that, E. coli O157:H7 strain known to be linked with waterborne outbreaks and causing high morbidity and mortality worldwide. Besides, the pathogen can survive for long periods of time in the water mostly in cold temperatures (Wang \& Doyle, 1998). The contamination of drinks served in restaurants may also come from the ice which is used to cool drinks and refrigerate foods such as fish and seafood.

Outbreaks of gastroenteritis due to contaminated ice have been reported (Khan et al., 1994; Pedalino et al., 2003) in other parts of the world. Trabulsi, Keller and Gomes (2002) concluded that typical enteropathogenic E. coli strain is the main cause of infantile diarrhoea in developing countries but rarely happen in industrialized countries. Other health disorders caused by E. coli are urinary tract infections, pulmonary infections, abscesses and skinwound infections. Moreover, those who were infected by the pathogen might be going through the process in which the incubation period takes three to four days after exposure or worst, short as one day. The incubation might as well take as long as 10 days' time. The early symptoms often start with mild belly pain or non-bloody diarrhoea that keep worsens after several days. Elexson et al. (2017) stated that exposures that result in illness include the intake of food unhygienically prepared, drinking unpasteurized (raw) milk, consuming disinfected water, having contact with bovine, or contact with the excrement of infected people. Some foods are considered to carry such a high risk of infection with E. coli 0157including raw milk, unpasteurized apple cider, and soft cheeses made from raw dairies. Sometimes, the contact is apparent (working with bovines at a dairy or changing diapers, for example), but sometimes it is not (like the consumption of an undercooked hamburger or a contaminated piece of lettuce) (Centre for Disease Control and Prevention [CDC], 2018). Poor water quality, improper food handling practices and poor hygienic conditions of places of food premises can be a major factor in the contamination of faecal coliform to the food and drinks they served the customer (Pandey, Kass, Soupir, Biswas and Singh, 2014). Other than that, ice can also be one of the sources of contamination of pathogenic bacteria because it is directly in contact with drinks and indirectly by refrigerating foods in the freezer (Ackers et al., 1998). The connection between contaminated ice and enteric diseases and the connection of infections and contaminated ice used in hospitals were mainly reported regarding the issue (Banatvala et al., 2008).

\section{CONCLUSION}

The study has confirmed that drinks from restaurants in Kota Samarahan were contaminated with total coliform bacteria. E. coli O157:H7 was detected in iced milo drinks collected from one of the food premises in Kota Samarahan. Hence, strict public-health regulations regarding the sale of foods and water by restaurants, regular laboratory checking for microbiological quality of served food and drinks to the consumers must be performed by local authorities to monitor the supply of potable water, good hygiene practices, food handling and environmental sanitation in food premises in Kota Samarahan to reduce the morbidity due to gastroenteritis in the study population.

\section{ACKNOWLEDGEMENT}

Research fund was sponsored by RAGS: E14099/F07/1314/2015(08) Universiti Malaysia Sarawak (UNIMAS) Kota Samarahan Sarawak, Malaysia. 


\section{REFERENCES}

Ackers, M. L., Mahon, B. E., Leahy, E., Goode, B., Damrow, T., Hayes, P. S., \& Griffin, P. M. (1998). An outbreak of Escherichia coli O157: H7 infections associated with leaf lettuce consumption. Journal of Infectious Diseases, 177(6), 1588-1593.

Baker, K., Morris, J., McCarthy, N., Saldana, L., Lowther, J., Collinson, A., \& Young, M. (2010). An outbreak of norovirus infection linked to oyster consumption at a UK restaurant, February 2010. Journal of Public Health, 33(2), 205-211.

Banatvala, N., Griffin, P. M., Greene, K. D., Barrett, T. J., Bibb, W. F., Green, J. H., \& Wells, J. G. (2001). The United States national prospective hemolytic uremic syndrome study: microbiologic, serologic, clinical, and epidemiologic findings. The Journal of Infectious Diseases, 183(7), 1063-1070.

Barile, M. F. (2012). Gram staining technique. Methods in Mycoplasmology V1: Mycoplasma Characterization, $1,39$.

Chai, L. C., Robin, T., Ragavan, U. M., Gunsalam, J. W., Bakar, F. A., Ghazali, F. M., Radu, S., \& Kumar, M. P. (2007). Thermophilic Campylobacter spp. in salad vegetables in Malaysia. International Journal of Food Microbiology, 117(1), 106-111.

Centre for Disease Control and Prevention, CDC. (2018). Multistate Outbreak of E. coli O157:H7 Infections Linked to Romaine Lettuce. Retrieved May 2, 2018, from https://www.cdc.gov/ecoli/2018/o157h7-0418/index.html.

Efstratiou, A., Ongerth, J. E., \& Karanis, P. (2017). Waterborne transmission of protozoan parasites: review of worldwide outbreaks-an update 2011-2016. Water research, 114, 14-22.

Elexson, N., Nik Yuhanis, F. N., Malcolm, T. T. H., New, C. Y., Chang, W. S., Ubong, A., Kuan, C. H., Loo, Y. Y., Thung, T. Y., \& Son, R. (2017). Occurrence of Escherichia coli harbouring stx genes in popiah, a Malaysian street food. Food Research, 1(1), 29-32.

Feng, P., Weagant, S. D., Grant, M. A., Burkhardt, W., Shellfish, M., \& Water, B. (2002). BAM: Enumeration of Escherichia coli and the Coliform Bacteria. Bacteriological Analytical Manual, 13-19.

Figueras, M., \& Borrego, J. J. (2010). New perspectives in monitoring drinking water microbial quality. International Journal of Environmental Research and Public Health, 7(12), 4179-4202.

Golan, E. H., Roberts, T., Salay, E., Caswell, J. A., Ollinger, M., \& Moore, D. L. (2004). Food safety innovation in the United States: evidence from the meat industry (No. 34083). United States Department of Agriculture, Economic Research Service.

Gerba, C. P. (2009). Indicator microorganisms. In Environmental Microbiology (2 ${ }^{\text {nd }}$ ed.). (pp. 485-499). Academic Press.

Gargano, J. W., Adam, E. A., Collier, S. A., Fullerton, K. E., Feinman, S. J., \& Beach, M. J. (2017). Mortality from selected diseases that can be transmitted by water-United States, 2003-2009. Journal of Water and Health, 15(3), 438-450.

Khan, A. S., Moe, C. L., Glass, R. I., Monroe, S. S., Estes, M. K., Chapman, L. E., \& Iskander, J. K. (1994). Norwalk virus-associated gastroenteritis traced to ice consumption aboard a cruise ship in Hawaii: comparison and application of molecular method-based assays. Journal of Clinical Microbiology, 32(2), 318322.

Leclerc, H., Schwartzbrod, L., \& Dei-Cas, E. (2002). Microbial agents associated with waterborne diseases. Critical reviews in microbiology, 28(4), 371-409.

Meng, J., Zhao, S., Doyle, M. P., Mitchell, S. E., \& Kresovich, S. (1997). A multiplex PCR for identifying Shigalike toxin-producing Escherichia coli O157: H7. Letters in Applied Microbiology, 24(3), 172-176.

Newell, D. G., Koopmans, M., Verhoef, L., Duizer, E., Aidara-Kane, A., Sprong, H., ... \& van der Giessen, J. (2010). Food-borne diseases - the challenges of 20 years ago still persist while new ones continue to emerge. International Journal of Food Microbiology, 139, S3-S15.

Pedalino, B., Feely, E., McKeown, P., Foley, B., Smyth, B., \& Moren, A. (2003). An outbreak of Norwalk-like viral gastroenteritis in holidaymakers travelling to Andorra, January-February 2002. Euro surveillance: bulletin européen sur les maladies transmissibles = European communicable disease bulletin .

Portier, C. J., Tart, K. T., Carter, S. R., Dilworth, C. H., Grambsch, A. E., Gohlke, J., \& Maslak, T. (2013). A human health perspective on climate change: a report outlining the research needs on the human health effects of climate change. Journal of Current Issues in Globalization, 6(4), 621.

Pandey, P. K., Kass, P. H., Soupir, M. L., Biswas, S., \& Singh, V. P. (2014). Contamination of water resources by pathogenic bacteria. AMB Express, 4, 51.

Rompré, A., Servais, P., Baudart, J., De-Roubin, M. R., \& Laurent, P. (2002). Detection and enumeration of coliforms in drinking water: current methods and emerging approaches. Journal of Microbiological Methods, 49(1), 31-54.

Tokuda, H., \& Matsuyama, S. I. (2004). Sorting of lipoproteins to the outer membrane in E. coli. Biochimica et Biophysica Acta (BBA)-Molecular Cell Research, 1693(1), 5-13. 
Trabulsi, L. R., Keller, R., \& Gomes, T. A. T. (2002). Typical and Atypical Enteropathogenic Escherichia coli. Emerging infectious diseases, 8(5), 508-513.

Uyttendaele, M., Jaykus, L. A., Amoah, P., Chiodini, A., Cunliffe, D., Jacxsens, L., Holvoet, K., Korsten, L., Lau, M., McClure, P., Medema, G., Sampers, I., \& Jasti, P. R. (2015). Microbial hazards in irrigation water: Standards, norms, and testing to manage use of water in fresh produce primary production. Comprehensive Reviews in Food Science and Food Safety, 14(4), 336-356.

Wang, G., \& Doyle, M. P. (1998). Survival of enterohemorrhagic Escherichia coli O157: H7 in water. Journal of food Protection, 61(6), 662-667.

World Health Organization, WHO. (1997). Guidelines for drinking-water quality. Volume 3, Surveillance and control of community supplies. World Health Organization.

World Health Organization, WHO. (2002). The world health report 2002: reducing risks, promoting healthy life. World Health Organization. 